\title{
A General View on Developments and Changes in Kheymeh Shab Bazi from the Qajar Dynasty to the Present
}

Saba Aslian, Maynooth University, County Kildare, Ireland sabaaslian@gmail.com

(C) 2016 University of Malaya. All rights reserved.

Malaysian Journal of Performing and Visual Arts, Volume 2, 2016

\begin{abstract}
Iranian marionette puppet theatre, Kheymeh Shab Bazi, developed dramatically from Qajar dynasty (1789) to the present in different aspects including puppets, dramatic literature, acting and structure of shows. In this paper, a general review on these changes and innovations that updated this traditional puppet show to the $21^{\text {st }}$ century's audiences is presented in two parts; developments in Kheymeh Shab Bazi during Qajar period (1789-1925), and innovations that occurred during last 90 years. Historical evidence including Figures, travel reports, literature and newspaper articles are used in this research.
\end{abstract}

Keywords: Kheymeh Shab Bazi, Iranian drama, entertainment in Iran, Iranian puppetry

\section{Introduction}

Puppet theatre or Namayesh-E-Aroosaki in Persian language, a portion of performing arts (Beyzayi, 2000), is found in traditional and modern forms. The traditional form of Iranian puppet theatre comprises of four main styles, including glove puppet, shadow puppet (Namayesh-E-khial in Persian literature, Namayesh-E-Sayeh in local language), and marionette puppet (Kheymeh Shab Bazi) (Kermani, 2006). 


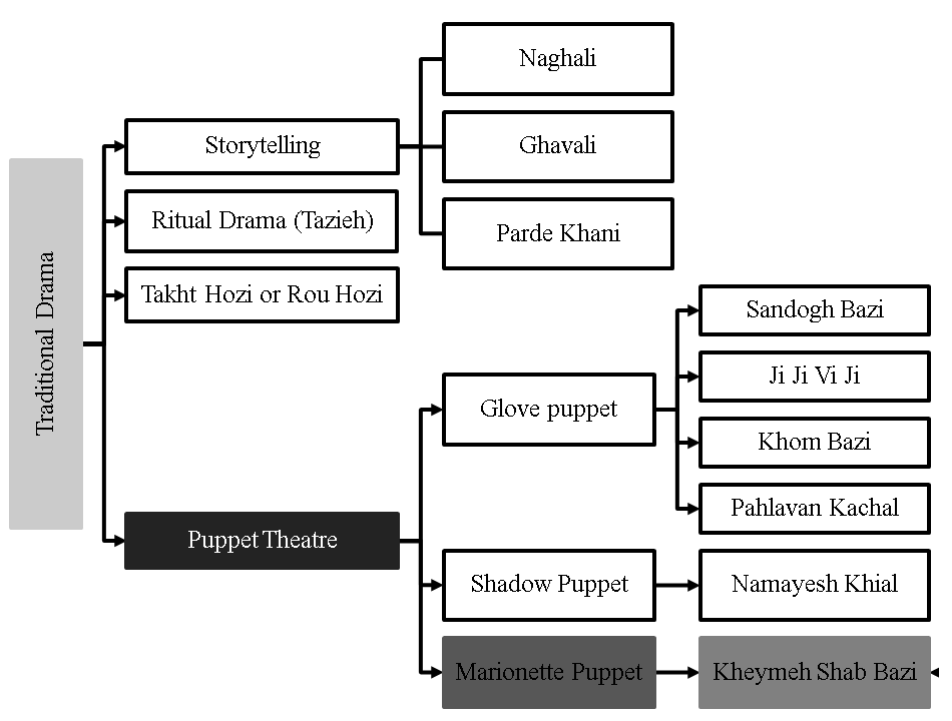

Figure 1. Classification of Iranian traditional drama

As seen in Figure 1, there are four traditional Iranian dramas and among all of them, puppet theatre and Takht Hozi or Rou Hozi (comedy shows) were performed purely for entertainment while Tazieh, Ghavali, Naghali and Parde Khani served both ritual and educational functions.

The Iranian traditional marionette puppet theatre, Kheymeh Shab Bazi, means to play in a small booth at night; this is evident from the three words, kheymeh (small booth), $s h a b$ (night) and bazi (play). The history of early Kheymeh Shab Bazi performance is obscure but it is speculated to have entered Iran from India during the $12^{\text {th }}$ century (Beyzayi, 2000).

Undoubtedly, there are numerous books and articles in the field of Iranian puppet theatre, but only a few specifically focus on Kheymeh Shab Bazi. For example: The History of Theatre in Iran (2005) by Willem Floor covers historical background of Iranian puppet theatre in his book; Iranian Ritual and Traditional Puppets and Puppet Shows Dictionary (2010) by Poupak Azimpour introduced puppets briefly; Yousof Seddigh's work entitled "A Research on Kheymeh Shab Bazi in Iran" (2004) added some information on techniques of puppetry in his book; and A Study of Iranian Theatre (2000) by Bahram Beyzayi is a reference book on the history of Iranian theatre including Iranian puppet shows. In addition, articles published in international journals such as "Kheimeh Shab Bazi: Iranian Traditional Marionette Theatre" by Shiva Massoudi (2009) and "Kheimeh Shab Bazi: Traditional Iranian Puppetry" by Simin Amirian (2014) reviewed previous historical and literary evidence and academically introduced Kheymeh Shab Bazi to the world. With respect to all previous studies on Kheymeh Shab Bazi, this paper will only focus on the developments and innovations in Kheymeh Shab Bazi from the Qajar dynasty (the golden age of Iranian performing arts) to the present. 


\section{Brief Introduction to Kheymeh Shab Bazi and its Elements}

The first literary evidence of Iranian puppet theatre is a poem by Nezami Ganjavi (2001), which indicates art exchanges between Iran and India in the $12^{\text {th }}$ century. Willem Floor believed that Indian puppetry influenced Persian pre-Islamic periods (before $7^{\text {th }}$ century). This can be proven by comparing the Kathputli marionette puppet show of Rajasthan, India, and Kheymeh Shab Bazi (Beyzayi, 2000; Baird, 2002). Nevertheless, Schafer's statement is conversely about the entrance of Kheymeh Shab Bazi from Ch'angan (or Jangan) village in northwest Iran, from Turkestan (Schafer, 1985). Figure 2 shows Kheymeh Shab Bazi and Kathputli performance.

Kheymeh Shab Bazi performances during $13^{\text {th }}, 14^{\text {th }}$, and $15^{\text {th }}$ centuries have been reported in Oshtornameh by Attar Neyshabouri, The Successors of Genghis Khan as well as in the poetry of Hafiz and Assar Tabrizi (Fazl Allah 1971; Beyzayi 2000; Attar Neyshaburi 2001; Floor 2005). Also, Mulla Hoseyn Va'ez Kashefi $\left(16^{\text {th }}\right.$ century) explained structure of performing Rooz Bazi glove puppet shows and Kheymeh Shab Bazi in his book (Sabzevari, 1971). The last documentation of Kheymeh Shab Bazi before the Qajar dynasty belongs to $17^{\text {th }}$ century when foreign ambassadors and travel reporters such as John Chardin initiated travels to Iran (Chardin, 1988).

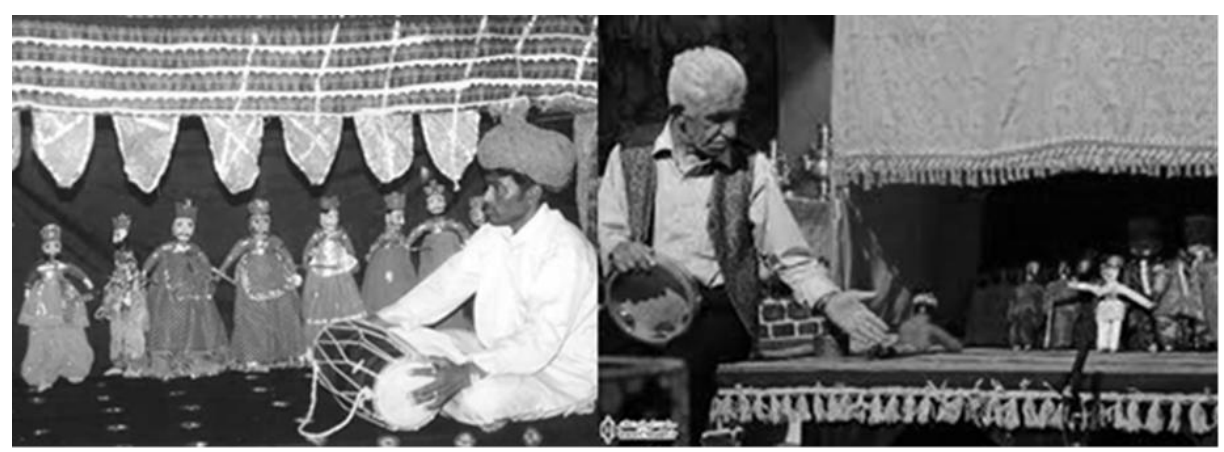

Figure 2. A. Kathputhli B. Kheymeh Shab Bazi

During the Qajar period, all kinds of traditional entertainment, including puppet theatre, became popular in both big and small cities (Beyzayi, 2000). Nevertheless, Western theatre started through performing translation of Moliere's scripts (Floor, 2005).

Short descriptions of Kheymeh Shab Bazi and its elements, summary of its story and structure of the show during the Qajar period is reported in Geography of Isfahan by Ibrahim Tahvildar Isfahani, Memories of Baha Allah, Travel Report of Aubin (19061907), and Sharhe Zendeganie Man by Mosofi (Beyzayi, 2000; Floor, 2005; Mostofi, 2005; Massoudi, 2009; Azimpour, 2010; Aubin, 2011). 
Kheymeh Shab Bazi is a musical puppet show that has four important elements: puppets, actor (Morshed), dramatic literature, and ensemble. Each show takes approximately one hour and usually begins with singing a well-known Iranian classical poem by the only actor of Kheymeh Shab Bazi, and playing classical music by an ensemble that is suitable for the poem.

Kheymeh Shab Bazi was basically based on improvisation and there was no dramatic litarature of Kheymeh Shab Bazi until researchers made some transcripts and recorded videos from live performances since 1970. There was no evidence of any Kheymeh Shab Bazi story plot before the Qajar dynasty. However, based on the masters of Kheymeh Shab Bazi, stories in Qajar dynasty came down from $17^{\text {th }}$ century because it was taught from one master to the next (Beyzayi, 2000). Two main stories of traditional Kheymeh Shab Bazi shows are known as Aroosie Pesare Salim Khan (The Wedding of Salim Khan's Son) and Mojazate yek Mojrem (The Trial of the Offender) (Beyzayi, 2000; Mostofi, 2005; Azimpour, 2010; Aubin, 2011).

Ordinarily, over half of a 70 or 80 Kheymeh Shab Bazi puppet set are used in one show (Azimpour, 2010). In the past, puppets were made of wood and fabric and in some cases, such as the puppet bride, plastic was used to create the heads of small dolls. Traditionally, a puppet's height varies from 20 and $30 \mathrm{~cm}$ according to their role. For instance, the puppet king is $29 \mathrm{~cm}$ and servant puppets are about $22 \mathrm{~cm}$ in height. The puppet collection is kept in a small box which was mostly received from one previous master. The puppets are manipulated through a wood handle (pasayi). Most traditional puppets are manipulated through the pasayi with two threads. Also, some puppets such as nurses or dancers are stuck to each other in a set that are manipulated together. A Kheymeh Shab Bazi puppeteer uses a hand-made instrument (safir) that is placed in his mouth to alter his voice. The only actor of the show, Morshed, Luti or Babay-E-Paye Kheymeh, who is usually an elderly man, is seated beside the kheymeh and repeats the puppeteer's words to make the story more comprehensible while he plays a musical instrument such as a tambourine (dayere zangi) (Azimpour, 2010). The kheymeh is a small room and is connected to a small stage that is about $30 \mathrm{~cm}$ high through a background fabric (tajir).

In a Kheymeh Shab Bazi performance music is used from the beginning to the end. There is no sheet music and music players play according to the rhythm of poems that they acquire from their previous shows. Morshed sometimes plays the tambourine to help the music ensemble in keeping rhythms.

\section{Developments and Changes in Kheymeh Shab Bazi during the Qajar Dynasty}

During the Qajar dynasty some of puppets and function of Kheymeh Shab Bazi changed gradually. There were three reasons behind these changes. Firstly, there were liberation movements against the government in society. Secondly, royal interest towards modernism led to importing inventions such as cars to Iran and, finally, opening modern schools and universities as a huge move to improve the education level of Iranians. It is necessary to mention that although there have been 
some changes in puppet costumes and designs, traditional puppets remained in the collections. Development in puppets is divided into two parts: adapting puppet costumes and face design according to common fashion during the Qajar period, and adding new puppets to the collection.

\section{Adapting the Costume and Design of Puppets}

\section{$\underline{\text { Aroos }}$}

Aroos (meaning bride) is a puppet wearing a Western-designed white dress (Figure 3). White bridal dresses became popular after the wedding of Queen Victoria in 1840. Prior to that, Iranian brides from specific areas wore dresses with traditional design that could be easily distinguished from traditional bridal designs of other areas and cities (Figure 4). For example, in south Iran brides wore red dresses for weddings.

Naser Al Din Shah, the most important king of the Qajar dynasty who reigned from 1848 to 1896, was interested in European modernism. He brought various European souvenirs from his travels to Iran, including dolls with white faces and white dresses. These dolls' dresses were miniature copies of wedding fashion trends in Europe. Moreover, the wives of foreign ambassadors or doctors wore dresses imitating European fashion which encouraged Iranian royal women to replace traditional wedding dresses with white gowns. The change in the Aroos puppet costume happened during or after Naser Al Din Shah's rule because previously, white gowns were never worn for weddings, even in cities.

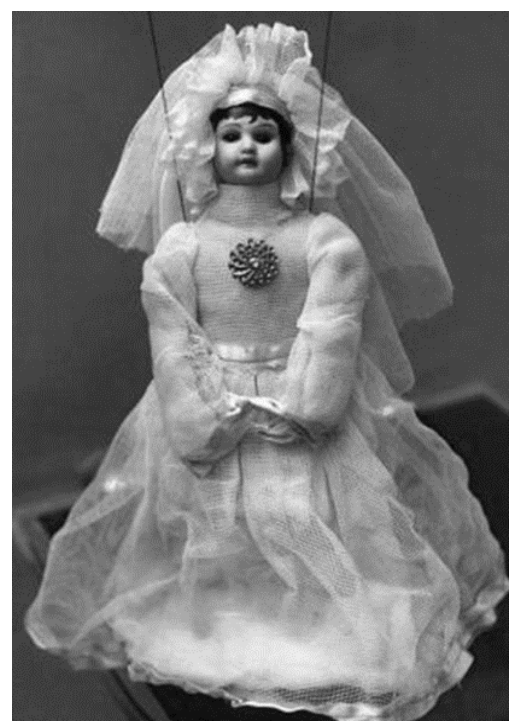

Figure 3. Aroos puppet 


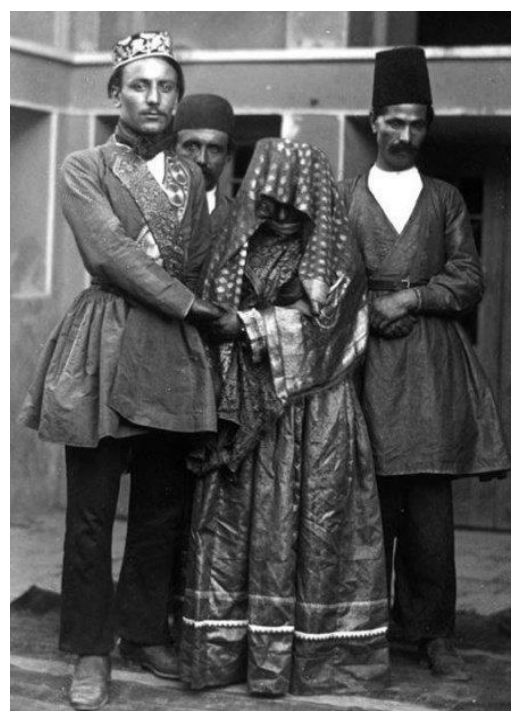

Figure 4. Iranian traditional wedding costume

\section{$\underline{\text { Mojrem }}$}

In a Kheymeh Shab Bazi performance, Mojrem (meaning criminal) is introduced in two ways: either he is captured for stealing something, or he is the manager of the royalty's entertainment and is accused of fraud by withholding the salaries of entertainers.

There is no evidence of when before or during the Qajar dynasty that the Mojrem puppet was added to the Kheymeh Shab Bazi puppet collection. Nevertheless, people who were arrested during this period are visually analogous with this puppet (Figures 5 and 6).

Through a close look at Figure 5, we can see that the prisoner's legs are fettered. Figure 6 shows the Mojrem puppet from the Puppet and Toy Museum of Iran whose legs are also fettered. The exact period in which this puppet was first created is obscure but since its design is exactly like the prisoners during the Qajar period, I believe that its design changed during this period when puppet makers tried to make it resemble a real criminal during the Qajar dynasty. 

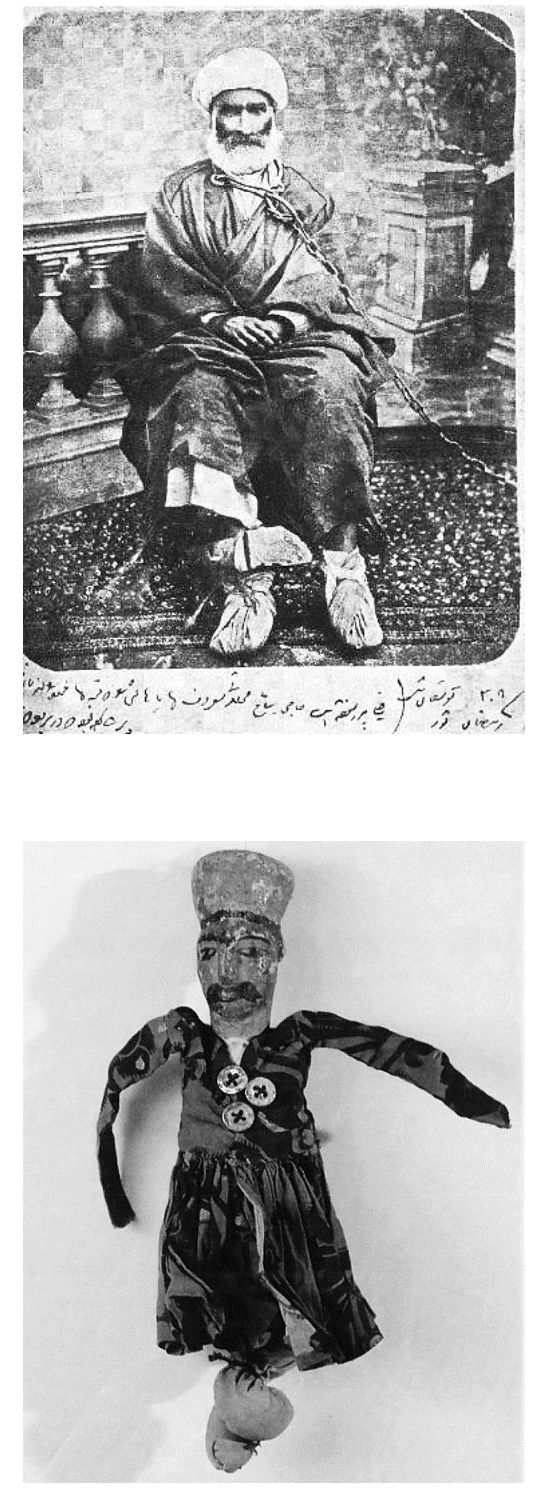

Figure 5. A prisoner with his legs fettered during the Qajar dynasty (Photo by Antoin Sevruguin)
Figure 6. Mojrem puppet with fettered legs (Photo by Javad Maleki)

\section{Zivar Ghabele}

The establishment of very first modern midwifery school with only ten students goes back to 1919 and eleven years later the gynecology department of Medical University established. However, midwives have always been respected for their ability to prevent a mother and her newborn baby from any serious or fatal delivery condition (Figure 7). Kheymeh Shab Bazi researchers are not sure who Zivar Ghabele (Zivar, the midwife) is. There are two hypotheses about it: firstly, around 200 years ago there was a respected and skilled midwife (ghabele) named Zivar who inspired a puppeteer to name his puppet Zivar Ghabele, and secondly this name was haphazardly selected by one puppeteer and other puppeteers followed him. 
Since midwifery has traditionally been a job for women from ancient times, the midwife puppet's costume design resembles local Muslim Iranian woman, particularly from the Qajar period. The puppet's costume, similar to Iranian Muslim women in big cities during the Qajar period (in villages traditional clothes were mostly used), include a black chador that is tightened around the waist and a white veil that covers its face (Figure 8). Interestingly, the Zivar Ghabele puppet contains a concealed newborn baby puppet under her chador and veil. In the performance, the Zivar Ghabele puppet first appears on stage with her chador and veil and once the delivery is over, uncovers the veil and presents the baby puppet (Figure 8).
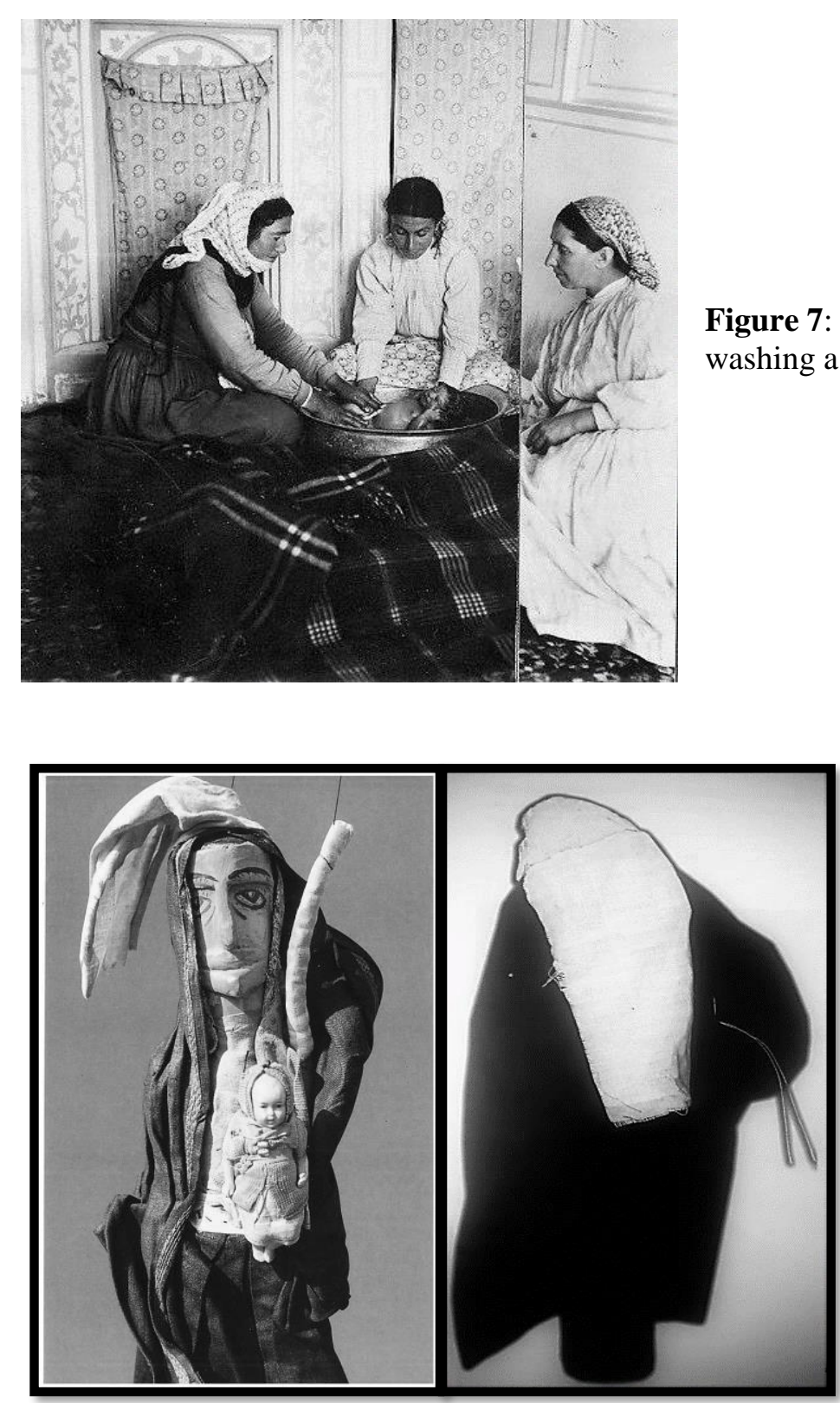

Figure 7: An Armenian midwife washing a newborn
Figure 8. Zivar Ghabele Puppet without (left) and with her veil (right) 


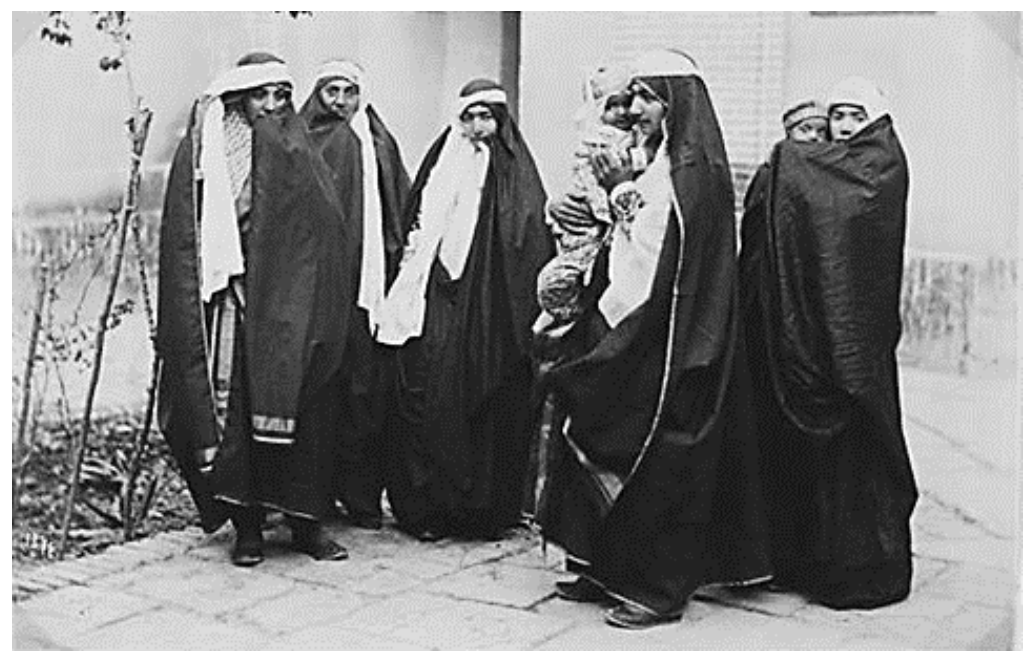

Figure 9. A

group of women during the Qajar period (Photo by Antoin Sevruguin)

\section{Adding New Puppets to the Collection}

\section{Doctor Bashi}

The history of ancient medicine in the Iranian plateau goes back to Aryan period when Terita cured patients through herbal medicines such as cinnamon. In the ancient world, war was an opportunity for scientists, artists, and writers to exchange books and knowledge. During several Greek-Persia wars, for example, the medical book of Hippocrates of Kos became available to Iranian physicians (Elgood, 1951).

After Islam, medical studies in Iran developed dramatically and produced outstanding Iranian physicians such as Mohammad Ibn Zakariya Razi and Avicenna (Ibn Sina/ Abu Ali Hosein Ibn Abdullah Ibn Sina/ Abu Ali Sina) with considerable intellectual ability and are able to conduct medical research. Ibn Sina (980-1037), for example, wrote over 400 books which are mostly about medicine and philosophy including the seminal work Ghanoun that has a detailed section on autopsy and was republished three times in 1973 in the United States of America (Elgood, 1951).

The very first modern medical school in Iran was in fact one of the most important departments of Dar-Al-Funun School, the very first institute of higher learning that was established in Tehran by then-prime minister, Mirza Taghi Khan Amir Kabir, in 1851. Jakob Eduard Polak, an Austrian physician and writer, was a medicine and surgery teacher between 1851 and 1860 and the personal doctor of then-King NaserAl-Din Shah simultaneously. Initially, Dr. Polak taught his courses in French with the help of a translator but soon he learned Farsi and even translated one medical book to Farsi for his first 14 students. He also established the first modern Army Hospital in 1854.

Before the foundation of medical school, doctors were called hakim. A hakim, as shown in Figure 10, specialized in herbal medicine, general hygiene, and basic home curing techniques from a previous hakim or his father. The hakim and ghabeleh were 
two people essential in caring for the ill and pregnant in Iran during this time (Elgood, 1951). The term Doctor Bashi was added to the Persian vocabulary after major changes in the medical system during Qajar dynasty. This is one of the reasons that all Kheymeh Shab Bazi researchers believe this puppet entered to the collection after 1851.

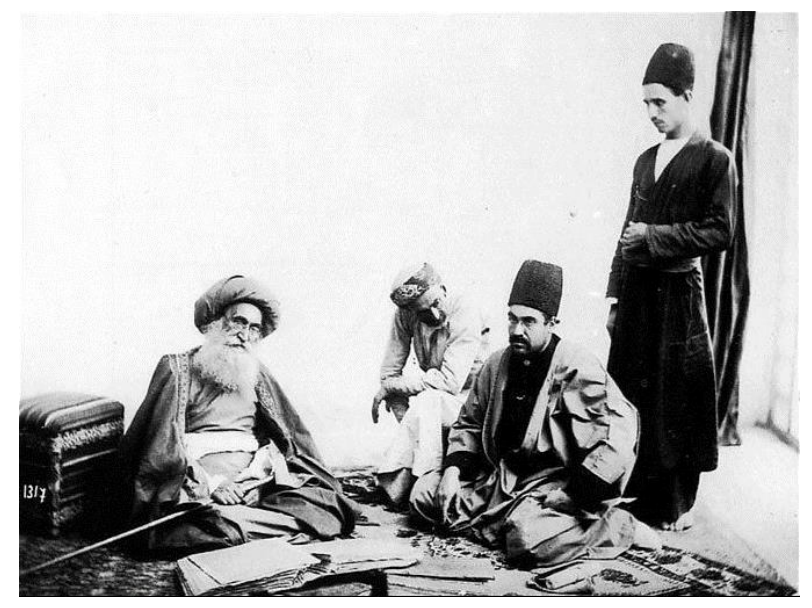

Figure 10. Hakim Bashi in Qajar period, before the emergence of modern doctors

The Doctor Bashi puppet enters the stage after a puppet such as the Jarou Kesh puppet becomes injured or collapsed. He usually confuses Morshed with the patient and after short comic dialogues, begins to inspect the puppet's condition. Then, he would chiefly order his nurses, two other puppets with a stretcher and ambulance (in recent shows), to take the patient to hospital.

The puppet's costume and design is similar to an actual doctor (Figure 11). Doctor Yousof Sedigh, who visited the personal puppet collection of Mr. Ahmadi, explained that this puppet has some belongings, including a small stethoscope and a medical bag. The most interesting part of its costume is the hat. This model was not used by Muslim local people in Iran. The main customers of this model were either foreigners or local Jews and Armenians. In fact, this hat fashion was first introduced in France where Dr. Tholozan (the personal doctor of Qajar kings for 30 years) came from. Moreover, Dr. Polak initially taught medical courses in French. There is no evidence on whether the puppet maker tried to imitate French fashion for Iranian puppets but obviously, he wanted this puppet to bear some resemblance to a foreigner or local non-Muslim. Figure 12, a family photo of Dr. Artin Estepanian (born 1870), the personal doctor of the king Mohammad Ali Shah, shows him wearing the same hat model. This proves that this particular hat was probably common among Jews, Armenians and foreigners in Iran. Therefore, it is possible that the puppet maker intentionally chose this hat and glasses to identify this puppet and character as a nonMuslim Iranian. 


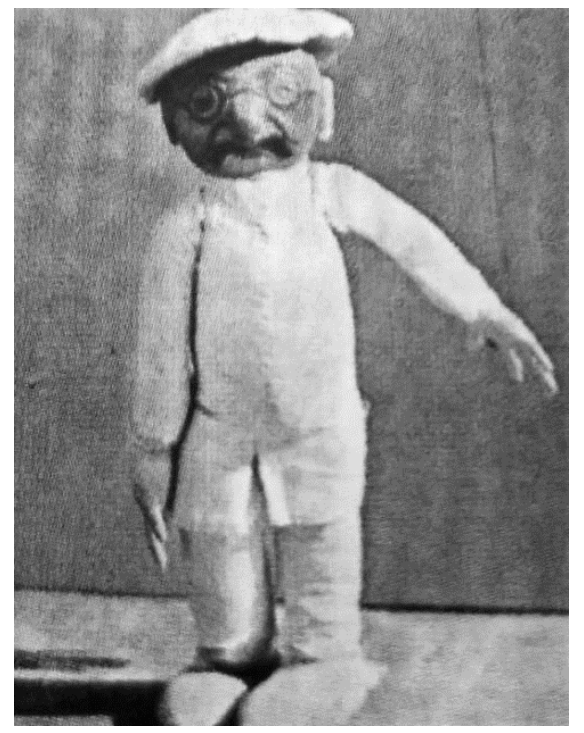

Figure 11. Doctor Bashi Puppet
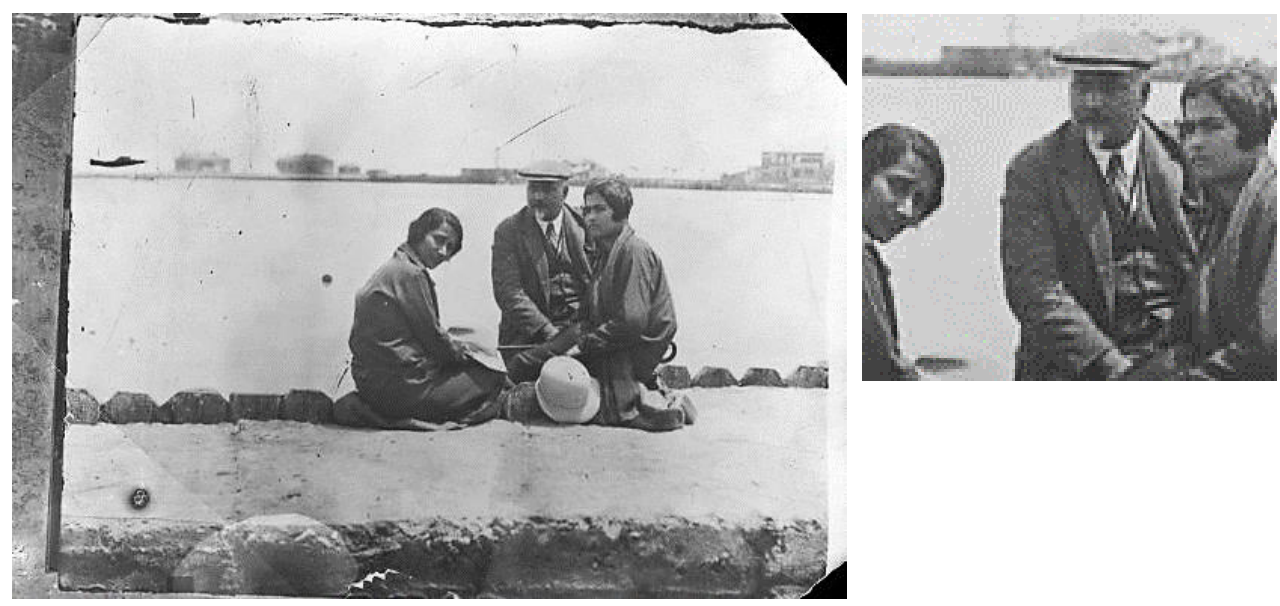

Figure 12. A family photo of Dr. Estepanian, detail (on right). (Avakian Collection of Qajar Women)

\section{$\underline{\text { Shoufer }}$}

Until beginning of $20^{\text {th }}$ century, Iranians used carriages with mostly one horse (except for the royal carriage with 4 horses) to transport to or between cities. These carriages were parked in the most crowded squares such as Toupkhane, Sabze Meydan, and Sarcheshmeh (Issawi, 2009). Figure 13A shows a carriage and its driver and Figure 13B shows the royal carriage of Naser Al Din Shah. These photographs were taken by Antoin Sevruguin, a famous photographer of Qajar dynasty. 


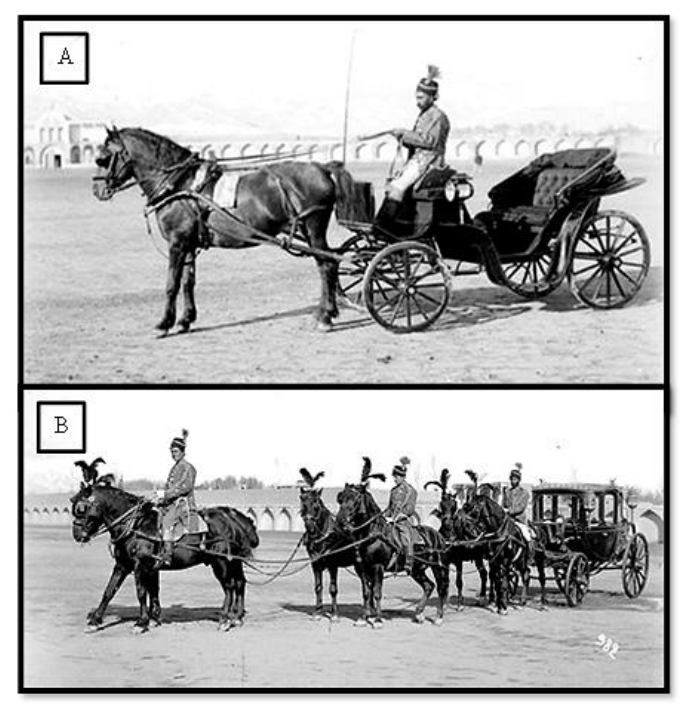

Figure 13. A. Carriage and the driver; B. Royal carriage and driver of Naser Al Din Shah during the Qajar dynasty. (Photo by Antoin Sevrugiun)

The Qajar king's interest to innovations in science and technology led to the importation of various inventions such as the camera and car to Iran. The first car was imported in 1902 from the Renault factory in France to Iran upon the order of the fifth king of the Qajar, Mozaffar Aldin Shah. Upon arrival in Iran, this car was rarely used and was kept in the garage of the court (Figure 14).

The driver (shoufer) was not a common job before the importation of cars to Iran and even during the reigns of the next two kings (Mohammad Ali Shah and Ahmad Shah), there was only a small community of drivers in Iran.

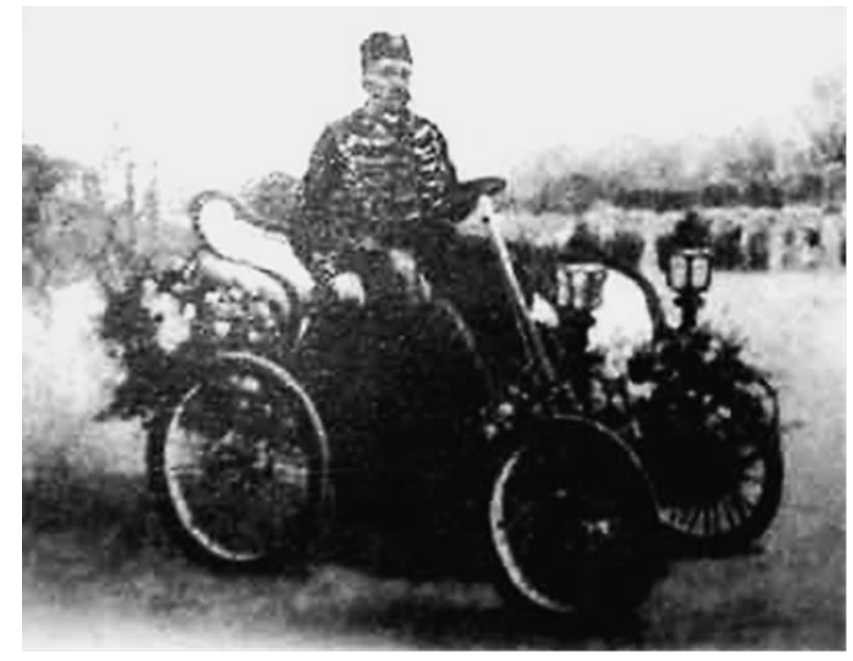

Figure 14. Muzaffar Aldin

Shah with his first car

The Shoufer puppet was added to the puppet collection after the import of cars into Iran in 1904, at the end of the Qajar period. Figure 15A indicates a Shoufer puppet with a car and Figure 15B is a 1904 model T car from the Renault Company in 1904. 
As seen, Shoufer is in a plastic miniature form of the car that is manipulated through four threads tied to the upper part of the car to increase the reality of picking up passengers. Although there are some horse puppets in the Kheymeh Shab Bazi collection, there is no carriage to show it was used for boarding puppets of king and royalties before 1902 .

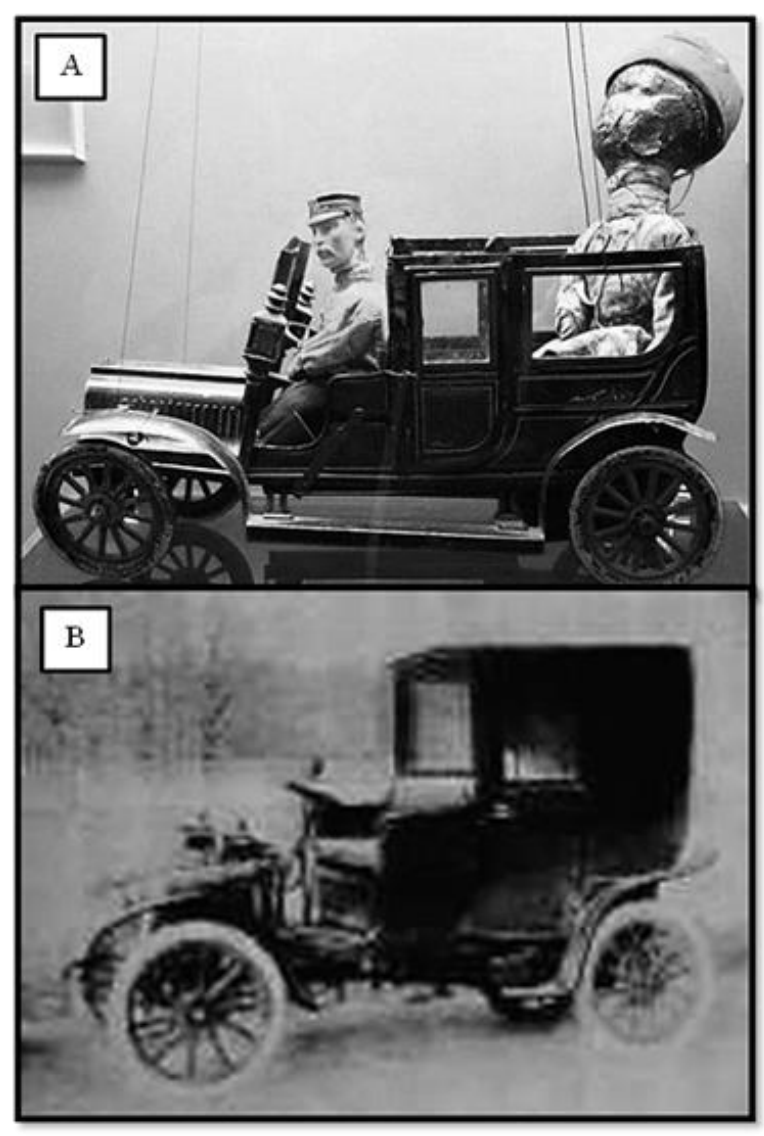

Figure 15. A. Shoufer Puppet (left) in the car with Mobarak (right) as his passenger (Azerbaijan Museum). B. Model $\mathrm{T}$ of Renault Company in 1904

\section{Vazir Mokhtar-E-Russ Va Engelis}

Vazir Mokhtar-E-Russ Va Engelis (meaning the Minister Plenipotentiary of England and Russia) were two important positions in the Qajar court. People of these positions were respected by both countries (Iran and Russia or Britain) because they had substantial influence on the domestic policies of Iran and king's decisions. For instance, Scot John McNeill initially came to Iran in 1823 as a medical officer but then took up a diplomatic position and eventually became minister plenipotentiary for over five years.

Unfortunately, these two puppets are unavailable and there are no figures of them. However, there is a report explaining that Vazir Mokhtar-E-Russ Va Engelis were two puppets who appeared on stage followed by the scoufer after the king indicates 
the puppeteer's intention to depict the social and political conditions in Iran of that time (Azimpour, 2010).

The Ministers' Puppets do not have any specific dialogue in the show. Nevertheless, they are more important than the other puppets and they are treated as royalty. For example, they are driven by the royal car after the king as special characters (Aubin, 2011). Moreover, the location of these puppets is different from other guests puppets from Turkey and India as they are positioned on both sides of the king.

\section{$\underline{\text { Parastaran }}$}

Unfortunately, researchers are faced with the lack of documentation to know the date of initial modern nursing activities in Iran although there are some reports of nurses (parastaran in modern Farsi and bimardar in old Farsi) in hospitals and darolshafa. According to historical researchers, the socio-political condition of northwest Iran suffered Ottoman attacks during the last three months of 1914 and was one of the reasons that increased the necessity of modern nursing training. Moreover, the presence of foreign nurses such as Miss Eston in West-Minister Hospital of Urmia and the medical activities of British doctors and nurses such as Miss Marry Bird in south Iran helped enable modern nursing trainings (Heydari and Fatemi, 2015). However, even prior to that, in 1893, non-academic nursing education began for girls, mostly Armenians and Jews, in American Missionaries Hospital in Tehran. This and the foundation of first modern hospital, Army Hospital, in 1854 introduced the position of parastaran in society, including puppeteers. With the initiation of the first nursing school in Urmia in 1916 and another one year later in Tehran, parastaran and nursing (parastari) became revered in Iran (Heydari and Fatemi, 2015).

The Parastaran puppets are of two men connected to each other through a stretcher. The puppet maker designed their costumes to resemble the nurses' uniform and some puppets have a cross on their hats to represent working for the Red Cross in Iran. These two puppets enter to stage together when a puppet (usually street cleaner) is injured and bring him to the hospital. The technique of moving these puppets is based on showing the puppets' profile to the audience at all times.

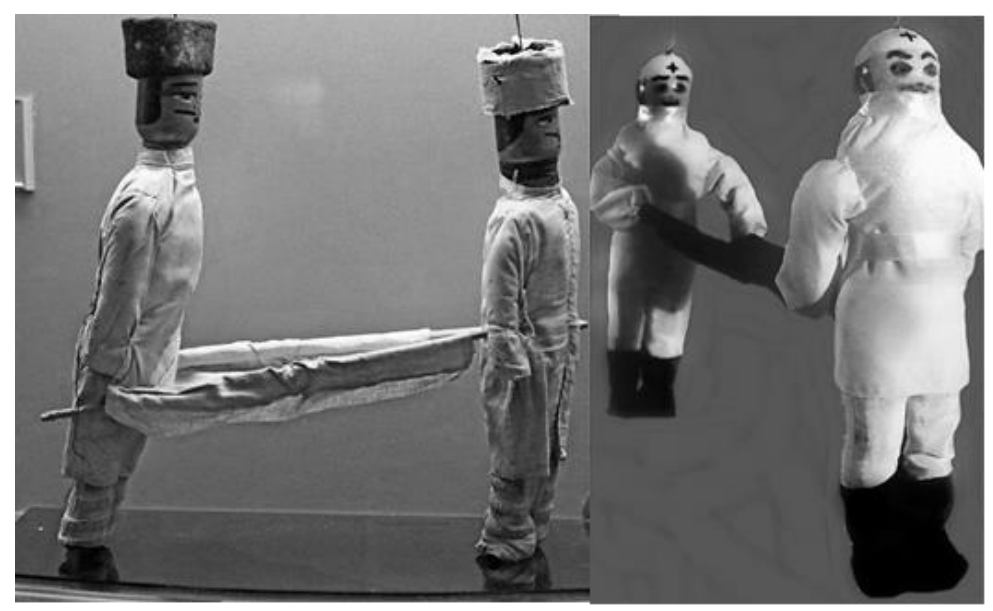

Figure 16. The

Parastaran puppets 


\section{Changes in Function of Kheymeh Shab Bazi during Qajar Dynasty}

The first function of Kheymeh Shab Bazi theatre is to entertain common people who are occupied with everyday routines although through these shows children could learn more about common jobs in society or basic moral principles such as respecting elders.

Based on conducted interviews with Kheymeh Shab Bazi masters by Bahram Beyzayi, at the end of Qajar dynasty these masters used Kheymeh Shab Bazi to improve Iranian knowledge of the political situation during the Qajar dynasty. In 1853, when Mozaffar Din Shah came to power and during his reign, liberation movements rose with the direct help of intellectuals and Muslim ecclesiastics which led to great political changes such as signing the constitutional law by the king (IRAJ, 2010). People from different social classes were involved in these social movements and Kheymeh Shab Bazi was used to push for these change. Nevertheless, author Amir Sohrabi and theatre researcher Davood Fath Ali Beygi rejected this theory in their interviews due to lack of evidence. Bahram Beyzayi, in contrast, believed that there are some possibilities that Kheymeh Shab Bazi performances served an apolitical function in the Qajar period. Poupak Azimpour also mentioned in her interview that if this hypothesis was accepted, they were probably performed with the commendation of opened-minded and educated people.

Thus, how did Kheymeh Shab Bazi performers use this show to change people's view of the political condition of Iran at the end of the Qajar period? To emphasize the influence of other countries on the political decisions of the king, Kheymeh Shab Bazi puppeteers wore Western suits similar to English politicians, came out of their booths and took the puppets' pasayi to signify that during the Qajar period foreigners, especially Minister plenipotentiary of England and Russia, directly intervened in their domestic affairs (Figure 17) (Beyzayi, 2000; Azimpour, 2010).

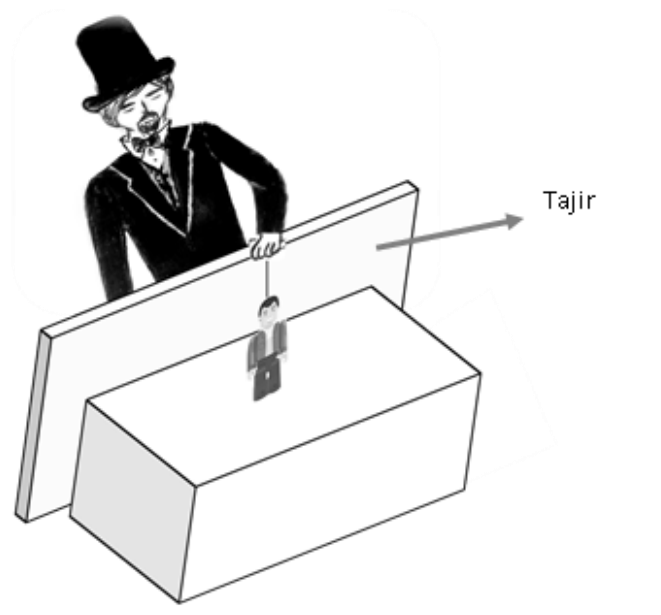

Figure 17. Sample Drawing of Puppeteer with British Clothes 


\section{Developments and Changes in Kheymeh Shab Bazi after the Qajar Dynasty to the Present}

The first evidence of Kheymeh Shab Bazi theatre after the Qajar dynasty is in 1932, seven years after the begining of Pahlavi period (1925-1979), by king Reza Pahlavi and performed for entertainment in social events such as birthday parties. During the past 85 years, there have been some innovations in puppet design, puppet-making techniques, puppetry methods, stories, and acting in Kheymeh Shab Bazi. Some of these changes, such as puppetry methods, are the result of theatre courses in Iranian arts universities through which students in theatre studies use modern puppetry methods in traditional theatre.

\section{Design of Puppets}

According to Sadegh Hedayat (2004), the numbers of puppets in a collection was still between 70 and 80 during the Pahlavi period and wood and fabric were used for puppet making. Reza Pahlavi tried to change all the traditions from the Qajar dynasty. For example, he ordered the change in the uniform and hats of soldiers. As a result, in Kheymeh Shab Bazi, the hats of soldier puppets was changed to the new hat model (kolah Pahlazi) used in the military service during Pahlavi period. Hats during the Pahlavi period were available in two models: the Kolah Pahlavi that was slightly bigger and more curved and stuck out at the front in comparison to the hat of Qajar period (Figure 18); and the kolah shapo that was a straw hat and usually colored black.

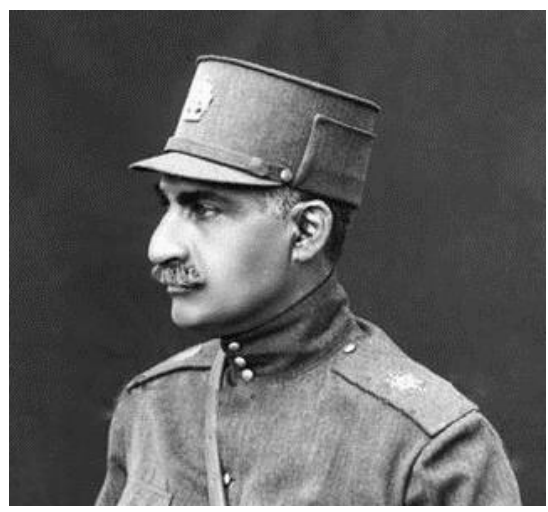

Figure 18. Reza Khan, the First King of the Pahlavi Dynasty, wearing a Pahlavi Hat (Hedayat, 2004)

During the Pahlavi period, traditional puppet theatre was categorized as commoners' entertainment that was suitable for children due to popularity of modern theatre and cinema. After the Islamic Revolution of Iran in 1979, traditional art improved and a new generation of theatre students started learning basic traditional performing arts from previous masters, and applied innovations in different aspects of traditional performances. As an example, students used new materials for puppet making and consequently changed the puppet-making process. Moreover, due to new forms of puppets, puppetry techniques changed as well. 


\section{New Puppets and Puppet Making Methods}

Kheymeh Shab Bazi puppets are now made according to new stories, leading to a major changes in the puppet collection. For example, the new story Mobarak Va Dive Sefid by Javad Tavalomi has a new character and puppet known as Ververeh Jadu. This character is an old ugly lady like a witch who creates problems for Mobarak, the protagonist in the story.

Techniques in puppet making also developed after the Islamic Revolution. Kheymeh Shab Bazi puppets are now made using both traditional and modern techniques. The traditional puppets are made from wood and fabric as in the past while Styrofoam is one common basic material used to create the heads of new puppets, and quicken its process (Figure 19). This material is covered by modeling paste and after drying it is smoothened using sandpaper; the end result is the heads are lightweight.

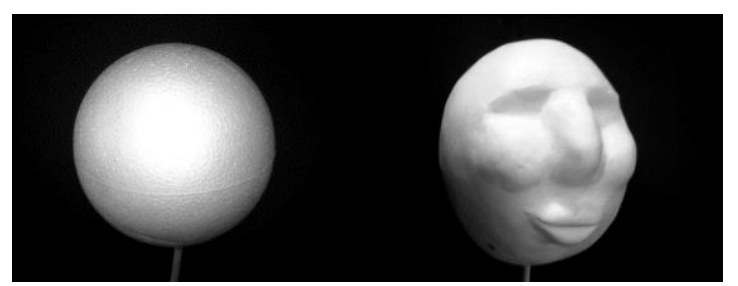

Figure 19. Puppet-making process using Styrofoam

\section{Puppetry Techniques}

Traditionally, the pasayi of Kheymeh Shab Bazi puppets are made of small sticks or a small cross. This has been altered to a newer form to enable better movement of the puppets' hands, legs, and back (Figure 20). For example, in the modern Kheymeh Shab Bazi show, Morovat Nameh Pahlavani, performed at the Bali Puppetry Festival and Seminar in 2013, the modern puppets used were made of Styrofoam, wood and fabric measuring 70 to $80 \mathrm{~cm}$ in height and manipulated through modern handles.

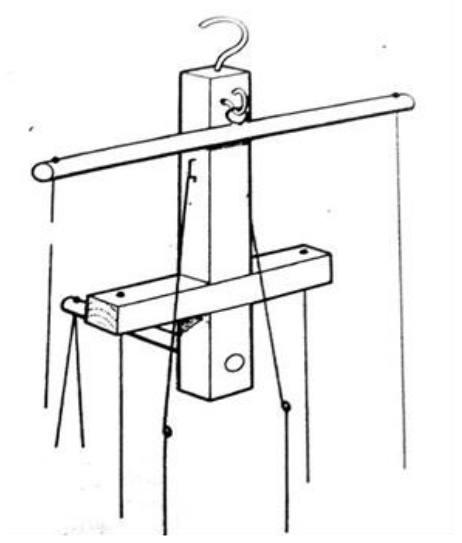

Figure 20: Modern handle for modern Kheymeh Shab Bazi puppets 


\section{Morshed}

Morshed is traditionally played by an elderly man with a tambourine. Changing this male role to a female role was an innovation in modern Kheymeh Shab Bazi. For the first time, a woman played the role of Morshed in a modern Kheymeh Shab Bazi performance at the Festival of Traditional Arts in Tehran in 2009 that was directed by myself. I explained that such changes can open the way to perform Kheymeh Shab Bazi in schools and kindergartens by teachers in order to keep this traditional puppetry alive. Now, there are Kheymeh Shab Bazi groups that are composed only of women.

\section{Story}

New Kheymeh Shab Bazi performances are usually based on written scripts by new writers like Mehdi Saffari Nezhad, Ali Shams, Behnaz Mehdi Khah, and Saba Moloudi, among others. Some modern Kheymeh Shab Bazi scripts are listed in Table 1. In these new scripts, the number and characters of puppets, and the function of Kheymeh Shab Bazi has changed dramatically.

Some of these scripts are written for the purposes of combining Kheymeh Shab Bazi and stage theatre such as Chahar Sandogh Shadi written by Naser Azhand. Also, the traditional visual or behavioral characteristics of protagonists and antagonists are changed in some modern Kheymeh Shab Bazi shows such as Bazichegan directed by Hasan Ravande. These modern Kheymeh Shab Bazi scripts have changed the entertainment function of Kheymeh Shab Bazi to become more didactic. Schools and kindergartens now invite new Kheymeh Shab Bazi groups to perform for children and educate them on cultural, moral, and religious principles.

\begin{tabular}{|l|l|l|l|}
\hline No. & Name & Script Writer & Director \\
\hline 1 & Chahar Sandogh Shadi & Naser Avizheh & Naser Avizheh \\
\hline 2 & $\begin{array}{l}\text { Na Dige In Vase Ma Dars } \\
\text { Nemisheh }\end{array}$ & $\begin{array}{l}\text { Behnaz Mehdi Khah/ } \\
\text { Gia Davodi }\end{array}$ & $\begin{array}{l}\text { Behnaz Mehdi Khah/ } \\
\text { Gia Davodi }\end{array}$ \\
\hline 3 & Morovvat Name Pahlavani & Mehdi Saffari Nezhad & Saba Aslian \\
\hline 4 & Bazichegan & $\begin{array}{l}\text { Govan Mehr Esmaeel } \\
\text { Pour }\end{array}$ & Hasan Ravande \\
\hline 5 & $\begin{array}{l}\text { Aroosi-E- Pesare Salim } \\
\text { Khan }\end{array}$ & Saba Moloudi & $\begin{array}{l}\text { Samira Yazdan } \\
\text { Pazhooh }\end{array}$ \\
\hline 6 & Mobarak Va Nasle Jadid & $\begin{array}{l}\text { Hamid Reza Haji } \\
\text { Molla Hosseini }\end{array}$ & Reza Bahrami \\
\hline 7 & Mobarak Va Terafik & Majid Alam Beydi & Majid Alam Beydi \\
\hline
\end{tabular}




\begin{tabular}{|l|l|l|l|}
\hline 8 & Haft Khane Mobarak & Ali Shams & Meysam Yousofi \\
\hline 9 & Golbaghali YekiYedooneh & $\begin{array}{l}\text { Behnaz Mehdi } \\
\text { Khah/Meysam } \\
\text { Beydaghi }\end{array}$ & $\begin{array}{l}\text { Behnaz Mehdi } \\
\text { Khah/Meysam } \\
\text { Beydaghi }\end{array}$ \\
\hline 10 & $\begin{array}{l}\text { Ghesehaye Mobarak va } \\
\text { Tabestan }\end{array}$ & Mona Sarbandi & Mona Sarbandi \\
\hline 11 & Mobarak Ashegh Mishavad & Amir Hossein Shafiyi & Amir Hossein Shafiyi \\
\hline
\end{tabular}

Table 1. Selected modern Kheymeh Shab Bazi scripts

\section{Conclusion}

The present research was conducted according to Cultural Memory theory through historical research methodology with the intention to study the components of Kheymeh Shab Bazi as a part of Iranian traditional culture through the analysis of historical evidence in order to understand the developments of Kheymeh Shab Bazi from the Qajar dynasty to the present.

Kheymeh Shab Bazi is a traditional Iranian marionette puppet theatre that changed during and after the Qajar dynasty in various aspects. The costumes of puppets such as Aroos were changed and new puppets such as Shoufer, Doctor Bashi and Parastaran were introduced and added to the previous puppet collection. Even after the Qajar period, these changes continued to take place during the past 85 years. New puppet theatre students have altered puppet-making methods and processes and introduced new materials such as Styrofoam as innovation to Kheymeh Shab Bazi. Moreover, they used modern puppetry techniques on various parts of the puppets' body for better manipulation. New scripts have also been written which changed the number of characters and introduced new puppets in Kheymeh Shab Bazi shows. These new scripts serve an educational function in addition to entertainment.

This research is definitely a start to study changes in Kheymeh Shab Bazi and other traditional kinds of puppet shows in Iran from different points of view.

\section{References}

Neyshaburi, M. I. E. A. (2001). Oshtornameh, Ushturnameh (انترنامه). Tehran: Community of Vestiges and Cultural Luminaries (انتشار ات انجمن آثار و مفاخر فرهنگى). pp. 20-22. 
Aubin, E. (2011). La Parse Daujourd Hui Iran Mesopotamie ( سفرنامه و خاطر ات اوزن (روطي (اوبن سفيرفر انسه در اير ان در آستانه جنبش مشروطيت Tehran: Elm. pp.54-60.

Azimpour, P. (2010). Iranian Ritual and Traditional Puppets and Puppet Shows Dictionary. Tehran: Namayesh. pp. 226-374.

Baird, W. B. (2002). The Art of Puppet (هنر عروسكى). Tehran: Norouz-e-Honar (موسسه فر هنگى و هنرنوروز هنر).pp. 32-40.

Beyzayi, B. (2000). A Study of Iranian Theatre. Tehran: Roshangaran \& Motaleate Zanan. pp. 84-112.

Chardin, S. J. (1988). Travel in Persia 1673-1677. New York: Dover Publications, Inc.

Kermani, F. N. Z. (2006). An Introduction to Drama(در آمدى بهنمايشنامه شناسى). Tehran: Sazman-e- Motalee va Tadvin -e- Kotob-e- Olum-e-Ensani-e- Daneshgah ha (SMT). pp. 85-87.

Elgood, C. (1951). A Medical History of Persia and the Eastern Caliphate; From the Earliest Times Until the Year A.D. 1932. Cambridge: Cambridge University Press. pp. $1-40$.

Fazl Allah, R. A. D. (1971). The Successors of Genghis Khan. New York: Columbia University Press. pp. 90-94.

Floor, W. M. (2005). The History of Theatre in Iran. Washington, D.C.: Mage Publishers. pp. 62-82.

Hedayat, S. (2004). Folk culture of the Iranian people. Tehran: Cheshmeh. pp. 2331.

Heydari, A. and S. N. Lotfi Fatemi (2015). Nursing Development in Iran during World Wars I and II: A Historical Study. Journal of Nursing and Midwifery Sciences. 1(2): 8.

IRAJ, R. (2010). Since Nadir Shah Afshar Till Ahmad Shah Qajar از نادرشاه افثاد ناه (از ) . (احمد شاه قاجار Mashhad: Ayin-e-Tarbiat, Sonboleh. pp. 45-60.

Issawi, C. P. (2009). The Economic History of Iran 1800-1914. Tehran: Gostareh (كستره). pp. 72-84.

Sabzevari, H. V. K. (1971). Fotovvat Nameh Soltani (فتوتنامه سلطانى). Tehran: Anthropological Research Institute and Cultural Studies ( بِّو هشغاه علوم انسانى و مطالعات ) فر هنگى)). pp. 50-62. 
Massoudi, S. (2009). Kheimeh Shab Bazi: Iranian Traditional Marionette Theatre. Asian Theatre Journal. 26(2): 20.

Mostofi, A. A. (2005). Description of My Life or Social and Official History of Qajar Period (شرح زندكانى من يا تاريخ اجتماعى و ادارى دوره قاجاريه). Tehran: Shahr-e-Ketab, Hermes. pp. 75- 90.

Ganjavi, H. A. A. G. N. (2001). Kooliate Nezami Ganjavi: Leyli-o- Majnoun, Haft Peykar, Khosro Shirin, Makhzan-al- Asrar, Eskandar Nameh. Tehran: Iran Sokhan Publications. pp. 132-153.

Schafer, E. H. (1985). The Golden Peaches of Samarkand: A study of Tangexotics. Berkeley, Los Angeles: University of California Press, p. 45-52.

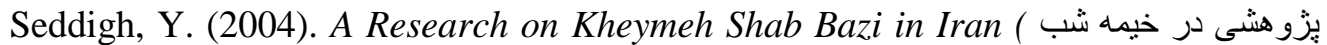
وزارت فرهنى و ارشاد اسلامى ، مركز (بازى در ايزان (هنر هاى نمايشى ، انتشار ات نمايش ان (رئر). pp. 69-71. 